\title{
The inertial loads of a telescopic boom of a truck crane
}

\author{
Volianiuk V. O. ${ }^{1}$, Gorbatyuk Ie. V. ${ }^{1}$, Mishchuk D. . $^{1}$ \\ ${ }^{1}$ Kyiv National University of Construction and Architecture, Ukraine
}

\begin{abstract}
Annotation. Problem. The analysis of existing research and publications in which the main problem is highlighted, namely, that many factors are not taken into account when calculating the inertial loads of the car crane arrows. Accounting for these factors will allow you to more accurately determine the inertial loads of the boom of the car crane, to carry out strength-hunches of the elements of the boom and the selection of components of its drive mechanisms. Goal. The purpose of the work is to determine the inertial navan-loads acting on the load and arrow of the automobile-side crane during the unstable movement of its. Methodology. To calculate the inertial loads, the technique of determining the total inertial loads of the car crane boom during joint operations in accordance with the Safety Regulations has been developed. Total inertial loads were determined for the following cases: joint lifting (lowering) of cargo and arrows; lifting the load and turning the boom; lifting and turning the arrow. Results. The resulting dependencies for determining the inertial loads of the rotary boom of the car crane will allow more accurately taking into account multiple factors to calculate the values of these loads in order to conduct strong calculations of the boom, the selection of its components mechanisms. Originality. When calculating inertial loads, the weight and length of the boom are taken into account; weight and height of lifting of cargo; the radius of the arrow crane; rotation speed of the rotary part of the crane; speed of movement of cargo and arrows; start time and braking of cargo lifting mechanisms, change of departure and turn of the boom. The advantage of this technique is its originality. Practical value. The use of this technique allows more accurately taking into account multiple factors to determine the values of the inertial loads of the automobile crane during the unstable movement of the cargo lifting mechanisms, changes in the discharge of the boom and its rotation in order to conduct strong-standing calculations of the boom elements, the selection of its components.
\end{abstract}

Key words: crane, boom, load, moment, inertia.

\section{Introduction}

Loading and unloading works are an integral part of the technological process of construction. Cranes and lifting mechanisms are mainly used to perform these works. Car cranes occupy the largest share of cranes used in construction, the main advantage of which is high mobility [1].

Mobile wheel cranes are used with mechanical, hydraulic and electrical drives of working equipment, with booms of constant length or with insert parts, retractable and telescopic. Currently, most often used car cranes with hydraulic drive and telescopic arrow.

Among the elements of the crane construction, a crane's booms is an important place which it's of characteristics and technical condition depends on the safety technique in the per- formance of loading and unloading operations and the prevention of trauma of the maintenance staff. The booms with a straight axis and an adjustable value of its departure are most widely used in automobile cranes [2].

When performing strong calculations of the boom, it is necessary to take into account all types of loads acting on the arrow, among which inertial loads occupy an important place. Inertial loads in the boom occur when it is unstable motion, that is, during the periods of acceleration and braking in the mechanisms of lifting the load, changes in the output of the boom and its rotation. The paper considers the definition of these loads taking into account multiple factors, which allows to more accurately determine their values $[3,4]$. 


\section{Analysis of publications}

The inertial characteristics of the crane's boom determine a significant part of the load that occurs during the transition processes of working with it and affect to the stability of the mobile crane, reliability and durability of its functioning and components of its drive. The importance of determining the inertial load on the crane arrow is of practical meaning and therefore this problem was reflected in a significant amount of modern research. For example, the works [5-8] show the general dependencies for determining inertial loads on the elements of the crane structure, its drive and arrow. However, in the received decisions, the authors do not take into account the influence of the deviation of the cargo under the action of centrifugal forces during the turn of the arrow.

Into work [9] represent the general dependencies for determining the inertial loads on the elements of the crane's structure. That work did not take account of the deviation of the loading under the action of centrifugal forces and the influence of the position of the equal force of inertia on the axis of the arrow, which does not coincide with the center mass of the boom. If to take account of these factors then it is possible to more accurately determine the inertial loads on the crane's boom and make calculations on the strength of the elements of the boom and components of its drive mechanisms. In an article [10] the influence of inertial loads of cargo and its deviation on the crane's boom was considered, but the peculiarities of determination of inertial loads for automobile cranes with telescopic arrow and hydraulic drive was not considered.

To determine the inertia forces acting on the crane boom, it is need to make its calculated load scheme. In the article [11], the design scheme is adopted in the form of a rectangular beam with a distributed load on its surface, and the full force of inertia is calculated through the integral from the elementary force of inertia. [12] does not take into account the position of the equal force of inertia on the axis of the arrow, which does not coincide with the center of mass of the arrow.

The work [13] contains dependencies for determining inertial loads on the design of boom self-propelled cranes, taking into account the above factors, but it does not contain features of determining inertial loads for telescopic booms with hydraulic drive.
The works $[14,15]$ show the dependencies for determining the maximum horizontal inertial forces acting on the load in the horizontal direction during the rotary movement of the crane boom, but there are no dependencies for determining the inertial loads acting on the arrow and vertical inertial loads acting on the load.

The works $[16,17]$ are devoted to the study of dynamic loader crane loaders, tower cranes and rotary crane during rotation. Inertial loads for car cranes were not considered in them.

An article [18] solves the problem of reducing the pendulum fluctuations of the load suspended on the rope in the process of turning the crane's boom. The crane's boom is seen as a holonomic system with a concentrated mass at its centre and a simplified inertial characteristic that reduces the accuracy of the calculations.

In the work [19], the authors similarly determine the parameters of the crane boom, where its exact inertial characteristics and design features are not taken into account and this further affects the reliability of the developed systems for quenching the oscillation of the boom.

In computer modeling of loads in the metal structure of a long flexible boom, the work [20] shows an uneven distribution of force factors in the processes of moving the boom, which can not be explained by the accurate definition of the inertial components of the boom.

Into an article [21] was presented how the inertial loads in the crane arrow affect its dynamics, but the exact way of determining such loads was not given.

\section{Purpose and Tasks}

The purpose of the work is to determine the inertial loads acting on the load and the telescopic boom of the car crane when its mechanisms are unstable.

In accordance with this goal, it is necessary to determine the dependencies for determining the quantities of inertial loads acting on the load and arrow of a car crane when its mechanisms are unstable, taking into account multiple factors to obtain more accurate values of these quantities.

The main task requiring a solution taking into account multiple factors is to determine the value of the inertial loads of the automobile crane in case of unstable movement of the cargo lifting mechanisms, changes in the output of the boom and its rotation in order to conduct strong calculations of the elements of the boom, the selection of its components. 


\section{Method for determining the inertial loads of a car crane boom}

According to the Rules of safety when performing work with a cargo crane, the driver is allowed to combine not more than two operations at the same time. In this regard, consider three main cases for determining the generated total moment of inertia of the rotary mobile crane's boom:

1. Lifting (lowering) the load and arrows.

2. Lifting (lowering) the load and turning the boom.

3. Lifting (lowering) and turning the boom.

During the period of unstable movement during the start and braking of the mechanism for lifting the load on the boom, an inertial load will act from the weight of the load, N:

$$
P_{l}=m_{l} \frac{d^{2} y_{l}}{d t^{2}}=m_{l} \frac{V_{l}}{t_{l}}
$$

where $m_{l}$ is load in $\mathrm{kg} ; y_{l}$ is vertical movement of cargo, $\mathrm{m} / \mathrm{s}^{2} ; V_{l}$ is lifting speed (lowering) of cargo, $\mathrm{m} / \mathrm{s} ; t_{l}$ is time of the unsuccessful operation of the mechanism of lifting the cargo (start and brake), s.

The moment of inertia forces created by vertical inertial forces when braking the mechanism of lifting the cargo is determined, $\mathrm{N} \cdot \mathrm{m}$ :

$$
M_{i}^{l}=m_{l} \frac{V_{l}}{t_{l}}\left(l-l_{o}\right) \cos \alpha,
$$

where $l$ is arrow length, $\mathrm{m} ; l_{o}, \alpha-$ crane's parameters (Fig. 1).

According to the safety rules, the slope of the crane when working on the ground is allowed $\gamma \leq 3^{\circ}$ (Fig. 1), therefore, when calculating the moments of inertia, this indicator is not taken into account.

The mass of the boom distributed along its length is advisable to replace the mass of the boom brought to the head. In this case, the inertial load from the mass of the boom when it is raised (lowered) will be, $\mathrm{N}$ :

$$
P_{i}^{a}=m_{a}^{b} \frac{d^{2} y_{a}}{d t^{2}}=m_{a}^{b} \frac{V_{a}}{t_{a}},
$$

where $m_{a}^{b}$ is mass of the arrow brought to her head, $\mathrm{kg} ; y_{a}$ is vertical movement of the head of the arrow, $\mathrm{m} / \mathrm{s}^{2} ; V_{a}$ is circular speed arrow head, $\mathrm{m} / \mathrm{s} ; t_{a}$ is time of unstable operation of the mechanism of change of the boom (start and brake), s.

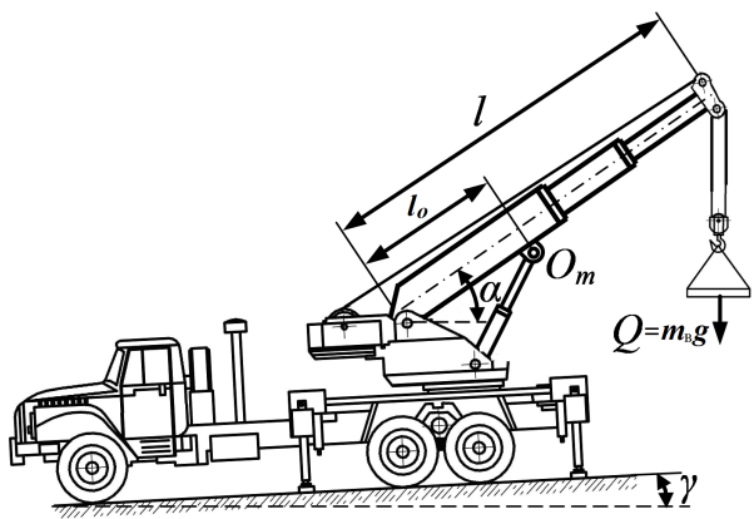

Fig. 1. The scheme to determine the moment of inertia of the boom with the load of a truck crane with hydraulic drive

The total inertial load from the weight of the load and boom during the period of unstable movement of the mechanism of change of the boom's departure will determine $\mathrm{N} \cdot \mathrm{m}$

$$
P_{i}^{a, l}=m_{l} \frac{V_{l}}{t_{l}}+m_{a}^{b} \frac{V_{a}}{t_{a}} .
$$

The moment of inertia forces arising from the masses of cargo and arrow, during the period of unstable movement during the operation of the mechanism of change of the arrow's departure will be $\mathrm{N} \cdot \mathrm{m}$

$$
M_{i}^{a, l}=\left[m_{l} \frac{V_{l}}{t_{l}}+m_{a}^{b} \frac{V_{a}}{t_{a}}\right]\left(l-l_{O}\right) \cos \alpha .
$$

Consider the inertial load telescopic boom car crane with straight longitudinal axis.

We assume that the mass of the boom is distributed evenly throughout its length, and the supporting hinge is in the middle of the main section, then the mass of the inertial part for the retractable boom $m_{i}=\frac{3 m_{l}}{4}$, for two-section telescopic $m_{i}=\frac{5 m_{l}}{6}$, a for three-section telescopic $m_{i}=\frac{7 m_{l}}{8}$. The most common in automobile cranes are two-section telescopic arrows. The mass of the elementary area for such an arrow will be, $\mathrm{kg}$ 


$$
d m=\frac{5 m_{a}}{6 l} d x
$$

where $m_{a}$ the mass of crane's boom, $\mathrm{kg} ; l$ the boom length, $\mathrm{m} ; d x$ the elementary section of the boom length, $\mathrm{m}$ (Fig. 2).

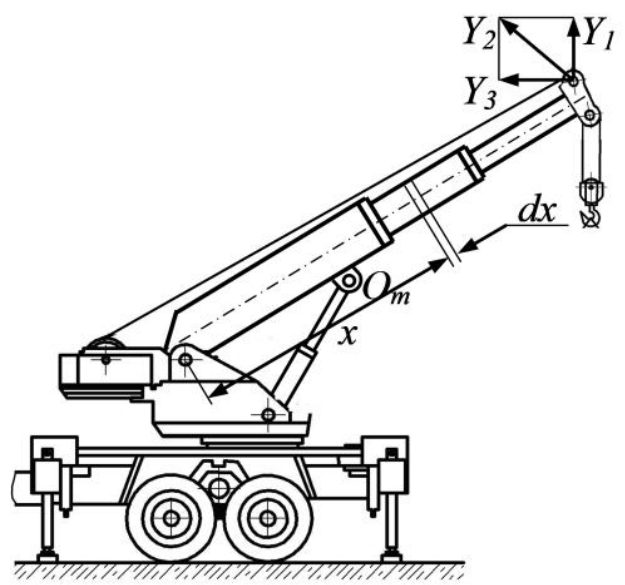

Fig. 2. Scheme for determining the total inertial load from the mass of a telescopic boom

The moment of inertia of the crane's boom to the axis of its heel when it is taken away will be, $\mathrm{kg} \cdot \mathrm{m}^{2}$ :

$$
d J=d m \rho^{2}=\frac{5 m_{a}}{6 l} x^{2} d x,
$$

where $\rho$ is centrifugal radius of arrow mass, $\mathrm{m}$; $x$ is distance from the support of the arrow to the elementary area of the arrow, $\mathrm{m}$.

The average acceleration of the mass of the entire boom relative to the hinge of its support, $1 / \mathrm{s}^{2}$ :

$$
\varepsilon=\frac{V_{a}}{t_{w} l}
$$

where $t_{w}$ is time of unstable operation of the mechanism of change the boom (start or brake) in seconds.

Moment of the forces of inertia of the boom from the mass, $\mathrm{N} \cdot \mathrm{m}$ :

$$
M=\int_{0}^{l} \frac{5 m_{a} V_{a}}{6 l^{2} t_{w}} x^{2} d x=\frac{5 m_{a} V_{a} l^{3}}{6 l^{2} t_{w} 3}=\frac{5 m_{a} V_{a} l}{18 t_{w}} .
$$

The resulting mass of the mobile crane's boom centered on its end creates a moment of inertia forces, as well as the moment from the actual uniformly distributed mass of the boom, $\mathrm{N} \cdot \mathrm{m}$ :

$$
\begin{aligned}
& M_{b}=J_{b} \varepsilon=m_{a}^{b} \rho^{2} \frac{V_{a}}{t_{w} l}=\frac{m_{a}^{b} l^{2} V_{a}}{t_{w} l}= \\
& =\frac{m_{a}^{b} l V_{a}}{t_{w}} .
\end{aligned}
$$

where $m_{a}^{b}$ is mass of the boom brought to her head, $\mathrm{kg} ; J_{b}$ is moment of inertia of the mass, focused on the end of the boom, $\mathrm{kg} \cdot \mathrm{m}^{2}$.

Equating the right parts of the equations (9) and (10), determine the value of the mass of the boom to its head:

$$
\frac{m m_{a}^{b} l V_{a}}{t_{w}}=\frac{5 m_{a} V_{a} l}{18 t_{w}} .
$$

From where:

$$
m_{a}^{b}=\frac{5 m_{a}}{18} .
$$

For a telescopic crane's boom, the mass distribution along its length can be approximately taken uniformly. If necessary, more accurate calculations can be the entire length of the boom divided into zones by sections, inside which the running mass of the boom does not change.

For each section of the boom distributed mass can be determined, $\mathrm{kg} / \mathrm{m}$

$$
m_{i}^{p}=m_{m s}^{p} k_{g},
$$

where $m_{m s}^{p}$ the mass of the main distributed section, $\mathrm{kg} / \mathrm{m} ; k_{g}$ is coefficient of change the geometric dimensions of cross section of next section. The values of this coefficient depend on the thickness of the walls of the telescopic boom sections. If you take their value as a constant, then the mass of each section of the arrow is equal to, $\mathrm{kg}$ :

$$
m_{i}=m_{i}^{p} l_{i} m_{i}=m_{i}^{\mathrm{\Pi}} l_{i},
$$

where $l_{i}$ is length of each section, $\mathrm{m}$.

The total moment of the inertial load relative to the hinge of the boom support is determinate in the future, which will be get as a result of summing the moment integrals for all arrow zones. 
The total moment of resistance created by inertia forces from the weight of the load and boom while simultaneously lifting (lowering) in the process of starting and braking will be recorded, $\mathrm{N} \cdot \mathrm{m}$

$$
M_{i}^{a, l}=\left[m_{l} \frac{V_{l}}{t_{l}}+m_{a} \frac{5 V_{a}}{18 t_{a}}\right]\left(l-l_{o}\right) \cos \alpha .
$$

The moment of resistance created by the centrifugal force of inertia of the load, which occurs when rotating the rotary part of the crane with the frequency during the acceleration (braking) of the rotation mechanism, is determined (Fig. 3), $N \cdot m$ :

$$
M_{i}^{c}=P_{c} h,
$$

where $P_{c}$ is centrifugal force, $\mathrm{N} ; h$ is distance from the level of the crane parking to the boom head, $m$.

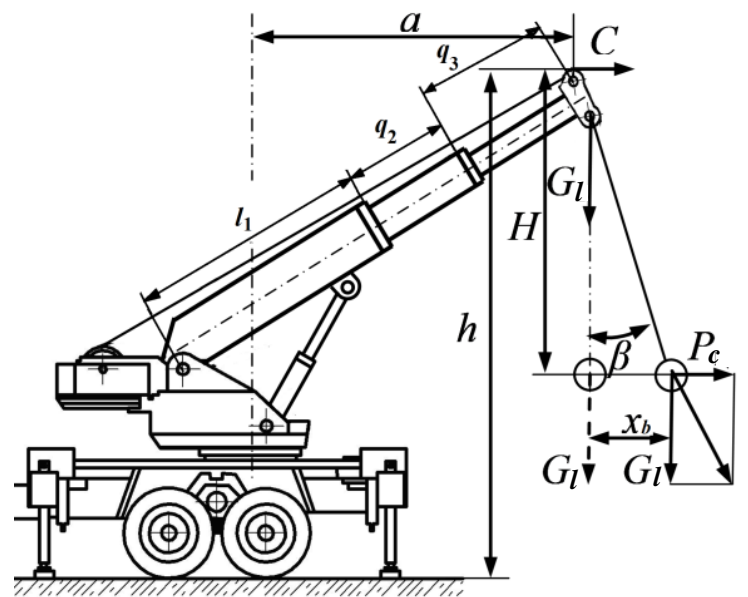

Fig. 3. Scheme to determine the moment of inertia created by the centrifugal force of the load, which occurs during the acceleration (braking) of the turning mechanism

The centrifugal force acting on the suspended load is equal to, $\mathrm{N}$ :

$$
P_{c}=m_{l} \omega^{2} \rho=\frac{G_{l}}{g} \frac{\pi^{2} n^{2}}{900}\left(a+x_{b}\right),
$$

where $G_{l}$ is load's force in $\mathrm{N} ; n$ is crane rotation speed, $\min ^{-1}$; $\omega$ is angular speed of rotation of the boom relative to the vertical axis, $\mathrm{s}^{-1} ; a$ is horizontal distance from the axis of rotation of the crane to the end of the boom, $\mathrm{m} ; x_{b}$ is distance of deviation of cargo under centrifugal force, $m$.
Value of cargo deviation under centrifugal force, $m$ :

$$
x_{b}=H \operatorname{tg} \beta ; \quad \frac{x_{b}}{H}=\frac{P_{c}}{G_{l}},
$$

where $H$ is vertical distance from the center of weight of the load to the head of the arrow, $m$.

From where:

$$
x_{b}=\frac{P_{c} H}{G_{l}} .
$$

Centrifugal radius, $\mathrm{m}$ :

$$
\rho=a+x_{b}=a+\frac{P_{c} H}{G_{l}} .
$$

Substituting and transforming we get, $\mathrm{N}$ :

$$
\begin{gathered}
P_{c}=m_{l} \frac{\pi^{2} n^{2}}{900}\left(a+\frac{P_{c} H}{G_{l}}\right) ; \\
P_{c}=\frac{G_{l} \pi^{2} n^{2} a}{g \cdot 900}+\frac{G_{l} \pi^{2} n^{2} P_{c} H}{g \cdot 900 G_{l}} ; \\
P_{c}-\frac{P_{c} n^{2} H}{900}=\frac{G_{l} n^{2} a}{900} .
\end{gathered}
$$

From where:

$$
P_{c}=\frac{G_{l} n^{2} a}{900-n^{2} H} .
$$

The moment of resistance to lifting the load that arises from its centrifugal force of inertia when turning the crane will be written, $\mathrm{N} \cdot \mathrm{m}$ :

$$
M_{i}^{c}=\frac{G_{l} n^{2} a h}{900-n^{2} H},
$$

where $h=\left(l_{1}+l_{2} k_{2}+l_{3} k_{3}\right) \sin \alpha+h_{k} ; h_{k}$ is vertical distance from the ground to the boom support, $\mathrm{m} ; k_{2}, k_{3}$ is coefficients of proportionality of nomination of sections boom, which are in the range from 0 to 0,$6 ; l_{1}, l_{2}, l_{3}$ is length of sections telescopic crane's boom, m; $a=\left(l_{1}+l_{2} k_{2}+l_{3} k_{3}\right) \cos \alpha-r, \mathrm{~m} ; r$ is distance from the axis of rotation of the crane to the five arrows, m (Fig. 4); $\alpha$ is angle of inclination of the arrow, grade. 
The moment of the inertia force from the weight of the load and the boom during the acceleration (braking) of the crane rotation mechanism is directed on the tangent to the trajectory of movement of these masses. Accurate calculation of this load is carried out taking into account the distribution of the mass of the boom along its length and taking into account the weight of the load.

The calculation of the equivalent weight of an arrow with the admission of a uniform distribution of its mass along the length is carried out by taking the axis of the arrow straight. Assuming that the mass of the arrow is evenly distributed along the inclined line, and the point of additional equal force of inertia does not coincide with the center of weight of the arrow, the position of the equal force on the axis of the arrow is determined. To this end, we determine the amount of inertia from the mass of the arrow.

Elementary mass of the arrow section is determined by (Fig. 4), kg:

$$
d m_{i}=\frac{m_{i}}{l_{i}} d x,
$$

where $m_{\mathrm{i}}$ is mass of the arrow section, $\mathrm{kg} ; l_{i}$ is length of the arrow section, $m$.

The moment of inertia of the main section of the arrow relative to the vertical axis of rotation, which is parallel to the axis of rotation of the crane and passes through the center of its mass$\mathrm{es}$, is equal to, $\mathrm{kg} \cdot \mathrm{m}^{2}$ :

$$
J_{01}=\int_{-\frac{1}{2} l_{1}}^{\frac{1}{2} l_{1}} \frac{m_{1}}{l_{1}} \cos ^{2} \alpha x^{2} d x=\frac{m_{1} l_{1}^{2}}{12} \cos ^{2} \alpha .
$$

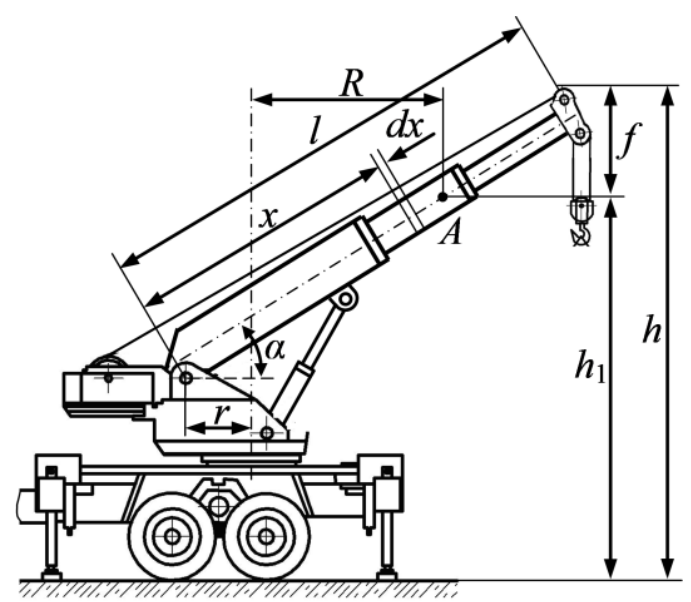

Fig. 4. Scheme for determining the elementary mass of telescopic boom
According to Steiner's theorem, the moment of inertia of the main section of the arrow relative to the rotation axis of the turning platform of the car crane will, $\mathrm{kg} \cdot \mathrm{m}^{2}$ :

$$
\begin{aligned}
& J_{1}=J_{01}+m_{1}\left(\frac{l_{1}}{2} \cos \alpha-r\right)^{2}= \\
& =\frac{1}{3} m_{1} l_{1}^{2} \cos ^{2} \alpha-m_{1} l_{1} r \cos \alpha+m_{1} r^{2} .
\end{aligned}
$$

Moments of inertia of the second and third retractable sections of the car crane telescopic boom, $\mathrm{kg} \cdot \mathrm{m}^{2}$ :

$$
\begin{aligned}
& J_{2}=\frac{m_{2} l_{2}^{2}}{12} \cos ^{2} \alpha+m_{2}\left(\rho_{2} \cos \alpha-r\right)^{2} ; \\
& J_{3}=\frac{m_{3} l_{3}^{2}}{12} \cos ^{2} \alpha+m_{3}\left(\rho_{3} \cos \alpha-r\right)^{2},
\end{aligned}
$$

where

$$
\rho_{2}=l_{1}+l_{2}\left(k_{2}-\frac{1}{2}\right), \rho_{3}=l_{1}+l_{2} k_{2}+l_{3}\left(k_{3}-\frac{1}{2}\right) \text {. }
$$

The total moment of the arrow's inertia will be equal to, $\mathrm{kg} \cdot \mathrm{m}^{2}$ :

$$
\begin{aligned}
J_{a}= & \frac{1}{3}\left(3\left(m_{1}+m_{2}+m_{3}\right) r^{2}-3 r\left(l_{1} m_{1}+l_{2} m_{2}+\right.\right. \\
& \left.+l_{3} m_{3}+2 m_{2} \rho_{2}+2 m_{3} \rho_{3}\right) \cos \alpha+ \\
& +\left(l_{1}^{2} m_{1}+m_{2}\left(l_{2}^{2}+3 l_{2} \rho_{2}+3 \rho_{2}^{2}\right)+\right. \\
& \left.\left.+m_{3}\left(l_{3}^{2}+3 l_{3} \rho_{3}+3 \rho_{3}^{2}\right)\right) \cos \alpha\right) .
\end{aligned}
$$

The moment of resistance to the rotation of the crane's boom from the forces of inertia of the arrow relative to the axis of its rotation will, $\mathrm{N} \cdot \mathrm{m}$ :

$$
M_{a}^{i}=J_{a} \frac{d \omega}{d t} \approx J_{a} \frac{\pi \cdot n}{30 t}=P_{a}^{i} R,
$$

where $t$ is time of unstable motion of the rotation mechanism, s; $P_{a}^{i}$ is equal force of boom inertia when turning it, $\mathrm{N} ; R$ is radius of the equal force of inertia, $\mathrm{m}$.

Elementary equal force of inertia boom, $\mathrm{N}$ :

$$
\begin{aligned}
& d P_{a}^{i}=d m \cdot \frac{d \mathrm{v}}{d t} \approx d m \cdot \frac{V_{a}}{t}=d m \cdot \frac{\omega}{t} l= \\
& =\frac{m_{a}}{l} \cdot \frac{\pi \cdot n}{30 t}(x \cos \alpha-r) d x .
\end{aligned}
$$


The full force of inertia from the mass of the boom that will act when the crane rotates will be, $\mathrm{N}$ :

$$
\begin{gathered}
P_{a}^{i}=\int_{0}^{l} \frac{m_{c} \pi n}{30 t l}(x \cos \alpha-r) d x= \\
=\int_{0}^{l} \frac{m_{a} \pi n}{30 t l} x \cos \alpha d x-\int_{0}^{l} \frac{m_{a} \pi n}{30 t l} r d x= \\
=\frac{m_{a} \pi n}{30 t l}\left(\frac{l^{2} \cos \alpha}{2}-r l\right)= \\
=\frac{m_{a} \pi n}{30 t}\left(\frac{l \cos \alpha}{2}-r\right) .
\end{gathered}
$$

We find the radius $R$ of the equal force of inertia on the axis of the arrow from the axis of rotation of the crane, $\mathrm{m}$ :

$$
R=\frac{M_{a}}{P_{a}^{i}}=\frac{J_{a}}{m_{a}\left(\frac{l \cos \alpha}{2}-r\right)},
$$

where the full length of the arrow can be found through its constituent sections and for the considered three-section arrow will $l=\left(l_{1}+l_{2} k_{2}+l_{3} k_{3}\right)$.

The height of applying the net force of the inertia of the boom when rotating the crane will be, $\mathrm{m}$ :

$$
h_{1}=h-f=\left(l_{1}+l_{2} k_{2}+l_{3} k_{3}\right) \sin \alpha+h_{k}-f \text {, }
$$

where

$$
f=\sin \alpha\left(l-\frac{R}{\cos \alpha}\right) .
$$

The moment of resistance of rotation from the inertia force of the load when rotating the crane will be, $\mathrm{N} \cdot \mathrm{m}$ :

$$
\begin{aligned}
M_{i}^{\text {t.c. }} & =m_{l}\left(a+\frac{P_{c} H}{G_{l}}\right)^{2} \frac{d \omega}{d t}= \\
& =m_{l}\left(a+\frac{P_{c} H}{G_{l}}\right)^{2} \frac{\pi \cdot n}{30 t} .
\end{aligned}
$$

The moment of resistance when rotating the crane with the load created by the total inertial load from the weight of the load and boom in the period of unstable movement of the crane rotation mechanism will be recorded, $\mathrm{N} \cdot \mathrm{m}$ :

$$
\begin{aligned}
& M_{i}^{t}=M_{i}^{t . c .}+M_{a}^{i}= \\
& =\left(J_{a}+m_{l}\left(a+\frac{P_{c} H}{G_{l}}\right)^{2}\right) \frac{\pi \cdot n}{30 t} .
\end{aligned}
$$

With simultaneous lifting (lowering) of the load and rotation of the crane, the total moment of resistance to lifting the boom from the inertia will be recorded, $\mathrm{N} \cdot \mathrm{m}$ :

$$
\begin{aligned}
& M_{i}^{b . l}=\left[m_{l} \frac{V_{l}}{t_{l}}\right]\left(l-l_{o}\right) \cos \alpha+\frac{G_{l} n^{2} a h}{900-n^{2} H}+ \\
& +\frac{m_{a} \pi n}{30 t}\left(\frac{l \cos \alpha}{2}-r\right) h_{1} .
\end{aligned}
$$

Thus, it is obtained dependencies for determining inertial loads from the mass of the load and boom for all three cases of compatible operation of the mechanisms of the car crane.

\section{Discussion of the results}

The resulting dependence of moments of inertia for a car crane with a telescopic arrow is significantly different from the expressions of moments of inertia for the crane's boom with a rope drive obtained earlier [10]. The divergence of the resulting dependencies shows that the design features of the mechanical crane system key to the nature of the change in inertial characteristics.

A preliminary analysis of the theoretical studies performed on the method of determining the inertial characteristics of the crane's boom showed that inertial overloads for the boom without pushing its sections and with the nomination of sections more than $60 \%$ of the length leads to an increase in the moments of inertia and corresponding supports by almost 2.3 times.

\section{Conclusion}

The above dependencies for determining the inertial loads from the mass of the load and boom for all three cases of compatible operation of the mechanisms of the car crane allow more accurately taking into account the multiple factors to determine the magnitude of the inertial loads of the car crane during the non-constant movement of the mechanisms of lifting the load, the change of the boom and its rotation in order to conduct strong calculations of the elements of the boom, the selection of its components of mechanisms.

In the future, it is necessary to develop programs to perform these calculations using computing machines. 


\section{Conflict of interests}

The authors declare that there is no conflict of interests regarding the publication of this paper.

\section{References}

1. Лівінський О. М. Курок О. І., Пелевін Л. С., Маліч В. О., Коваленко В. М., Бабиченко В. Я., Русан І. В., Волянюк В. О., Міщук Д. О., Мачишин Г. М. (2016). Підйомнотранспортні та вантажно-розвантажувальні машини: підручник. Київ: “МП Леся”. 676 с. Livinsky O, Kurok O, Pelevin L, Malich V, Kovalenko V, Babichenko V, Rusan I, Volianiuk V, Mishchuk D, Machishin G. (2016). Pidjomno-transportni ta vantazhnorozvantazhuval'ni mashyny. [Lifting and transport and loading and unloading machines]. Kyiv: "LE Lesia". [in Ukrainian].

2. Баладінський В. Л., Русан I. В., Гаркавенко О. М., Вольтерс О. Ю. (2005). Пристрої та механізми вантажопідйомних машин: навч. посіб. Київ: КНУБА. 132 с. Baladins'kij V., Rusan I., Garkavenko O., Vol'ters O. (2005). Pristroï ta mehanizmi vantazhopidjomnih mashin [Devices and mechanisms of lifting machines]. Kyiv: KNUCA. [in Ukrainian].

3. Гончарук О. М., Стрілець В. М. (2006). Вантажопідйомна, транспортуюча та транспортна техніка: навч. посіб. Рівне: НУВГП, 345 с. Goncharuk O., Strilec' V. (2006). Vantazhopidjomna, transportujucha ta transportna tehnika. [Lifting, transporting and transport machinery]. Rivne: NUVGP. [in Ukrainian].

4. Abdel-Rahman E. M., Naufen A. H., Masoud Z. N. (2003). Dynamics and Control of Cranes: A Review. Journal of Vibration and Control, 9 (7), 863-908. https://doi.org/10.1177/1077546303009007007.

5. Yasunari Kawabata, Translated by Edward G. Seidensticker (2011). Thousand Cranes. London, United Kingdom.

6. Sherri Duskey Rinker, Ethan Long. (2019). Crane Truck's Opposites: Goodnight, Goodnight, Construction Site (Educational Construction Truck Book for Preschoolers, Vehicle and Truck Themed Board Book for 5 to 6 Year Olds, Opposite Book). Chronicle Books; Illustrated edition.

7. Kathryn Clay. (2016). Cranes (Construction Vehicles at Work). Capstone Press; Large type / Large print edition.

8. Dickie D. E. (2013) Crane Handbook. Butterworth-Heinemann.

9. Бондарєв В. С., Дубінець О. І., Колісник М. П. (2009). Підйомно-транспортні машини: Розрахунки підіймальних i транспортувальних машин: підручник. Київ: Вища шк. 373 с. Bondarev V., Dubinec' I., Kolisnik M. (2009). Pidjomno-transportni mashini: Rozrahunki pidijmal'nih i transportuval'nih mashin. [Lifting and transport machines: Calculations of lifting and transporting machines]. Kyiv: High school. [in Ukrainian].

10. Volyanyuk V., Mishchuk D., Horbatyuk Ye. (2020). Vyznachennya inertsiynykh navantazhen' povorotnoyi strily samokhidnoho strilovoho krana. "Mining, construction, road and reclamation machines", 96, 13-21. https://doi.org/10.3247/gbdmm2020.96.05.25.

11. Іванченко Ф. К. (1993). Підйомно-транспортні машини: підручник. Київ: Вища школа, 413 с. Ivanchenko F. (1993). Pidyomno-transportni mashyny. [Machine pidemno-transport]. Kyiv: High school. [in Ukrainian].

12. Amanda Askew. (2020). Cranes (Mighty Machines). Firefly Books; Illustrated edition (July 1, 2020).

13. Волянюк В. О., Горбатюк С. В. (2021). Розрахунок механізмів вантажопідіймальних машин: навч. посіб. Київ: КНУБА. 136 с. Voljanjuk V., Gorbatjuk Ie. (2021). Rozrahunok mehanizmiv vantazhopidijmal'nih mashin. [Calculation of mechanisms of lifting machines]. Kyiv: KNUCA. [in Ukrainian].

14. German B., \& Cramar J. (2008). A study of the horizontal inertial forces acting on the suspended load of slewing cranes. International Journal of Mechanical Sciences. 50 (3), 490-500. https://doi.org/10.1016/j.ijmecsci.2007.09.013.

15. Rupar D., Hladnik J., Jerman B. (2016). Loader Crane Inertial forces. Transactions (2016) 44, 291-297. https://doi.org/10.5937/fmet1603291R.

16. Ju F., Choo Y. S., Cui F. S. (2006). Dynamic response of tower crane induced by the pendulum motion of the payload. International Journal of Solids and Structures.43 (2). 376-389. https://doi.org/10.1016/j.ijsolstr.2005.03.078.

17. XB. Jerman, P.Podržaj, J.Kramar. (2004). An investigation of slewing-crane dynamics during slewing motion-development and verification of a mathematical model. International Journal of Mechanical Sciences. 46 (5). 729-750. https://doi.org/10.1016/j.ijmecsci.2004.05.006.

18. Perig A. V. Stadnik A. N. Deriglazov A. I. (2014) Spherical pendulum small oscillations for slewing crane motion. Scientific world journal, 451804.

19. Yoon J., Nation S., Singhose W., Vaughan J. E. (2014). Control of crane payloads that bounce during hoisting. IEEE Transactions on Control Systems Technology, Vol. 22, 3, 1233-1238, https://doi.org/10.1109/TCST.2013.2264288.

20. Cao X., Yang Y., Wang W., Gu Z. (2017). RigidFlexible Coupling Dynamic Modeling of a Tower Crane with Long Flexible Boom. Mechanisms and Machine Science. Springer, Singapore. https://doi.org/10.1007/978-981-106553-8_4.

21. Yan Shijun Peng, Jian Ren, Zhongjun Wang Shiming. (2020). Dynamics of a flexible multibody hoisting system based on an equivalent 
simplified model. Journal of vibration and shock, 39(18), 255-261.

Volianiuk Volodymyr ${ }^{1}$, PhD, Assoc. Prof. Department of Construction Machinery, e-mail: volian535@ukr.net, tel.: +38-066-384-28-70, ORCID: 0000-0002-6852-9037

Gorbatyuk Ievgenii ${ }^{1}$, PhD, Assoc. Prof. Department of Construction Machinery,

gek_gor@i.ua, tel.: +38-067-910-59-43,

ORCID: 0000-0002-8148-5323

Mishchuk Dmitry ${ }^{2}$, PhD, Assoc. Prof. Department of Construction Machinery,

tdmid@ukr.net, tel. +38-097-175-53-41, ORCID: 0000-0002-8263-9400

${ }^{1}$ Kyiv National University of Construction and Architecture, Povitroflotskyi ave., 31, Kyiv, Ukraine, 03037

\section{Інерційні навантаження телескопічної стріли автомобільного крана}

Анотація. Проблема. Проведено аналіз існуючих досліджень $і$ публікацій, в яких виділена основна проблема, а саме, щчо при розрахунках інериійних навантажень стріли автомобільного крана не враховуються багато факторів. Облік ичих факторів дозволить більш точно визначати інериійні навантаження стріли автомобільного крана, проводити мічнісні розрахунки елементів стріли і підбір складових механізмів ї̈ приводу. Мета. Метою роботи є визначення інериійних навантажень, щчо діють на вантаж $i$ стрілу автомобільного крана при несталому русі його механізмів. Методологія. Для розрахунку інериійних навантажень розроблена методика визначення сумарних інериійних навантажень стріли автомобільного крана при виконанні спільних операцій відповідно до Правил техніки безпеки. Сумарні інериійні навантаження визначалися для таких випадків: спільний підйом (опускання) вантажу $i$ стріли; підйом (опускання) вантажу $і$ поворот стріли; підйом (опускання) $i$ поворот стріли. Результати.
Отримані залежності для визначення інериійних навантажень поворотної стріли автомобільного крана дозволять більш точно з врахуванням множинних факторів обраховувати значення ичих навантажень з метою проведення міџністних розрахунків стріли, підбору складових механізмів підіймання вантажу, зміни вильоту стріли та повороту крана. Оригінальність. При розрахунках інериійних навантажень враховуються такі вихідні дані: маса і довжина стріли; маса і висота підйому вантажу; радіус дї стріли крана; частота обертання поворотної частини крана; швидкості переміщення вантажу i стріли; час пуску та гальмування механізмів підйому вантажу, зміни вильоту та повороту стріли. Перевагою наведеної методики $є$ ї̈ оригінальність. Практичне значення. Застосування наведеної методики дозволяє більш точно з урахуванням множинних факторів визначати величини інериійних навантажень автомобільного крана при несталому русі механізмів підйому вантажу, зміни вильоту стріли та ї̈ повороту з метою проведення міиністних розрахунків елементів стріли, підбору складових ї̈ механізмів.

Ключові слова: кран, стріла, вантаж, момент, інериія.

Волянюк Володимир Олександрович ${ }^{1}$, к.т.н., доцент кафедри будівельних машин, volian535@ukr.net, тел.: +38-066-384-28-70,

ORCID: 0000-0002-6852-9037

Горбатюк Євгеній Володимирович ${ }^{1}$, к.т.н., доцент кафедри будівельних машин,

gek_gor@i.ua, тел.: +38-067-910-59-43,

ORCID: 0000-0002-8148-5323

Міщук Дмитро Олександрович ${ }^{1}$, к.т.н., доцент кафедри будівельних машин, tdmid@ukr.net, тел. 38-097-175-53-41, ORCID: 0000-0002-8263-9400

${ }^{1}$ Київський національний університет будівництва i архітектури, пр. Повітрофлотський, 31, м. Київ, Україна, 03037. 